\title{
ВІКТИМОЛОГІЧНА ХАРАКТЕРИСТИКА КОРИСЛИВИХ ЗЛОЧИНІВ ПРОТИ ВЛАСНОСТІ У ВЕЛИКОМУ МІСТІ ПРИЧОРНОМОРСЬКОГО РЕГІОНУ: УРБАНІСТИЧНИЙ І РЕГІОНАЛЬНИЙ ВИМІР
}

Остроглядов О. I.

у статті представлено результати віктимологічної характеристики корисливих злочинів проти власності у великому місті Причорноморського регіону України. Констатовано, що пізнання феномена віктимізації населення $\epsilon$ одним із найважливіших шляхів інформування населення з метою його захисту від корисливих злочинів проти власності.

Сформульовано узагальнений портрет жертви корисливих злочинів проти власності у великому місті Причорномор'я України. Установлено, що щорічно в нашій країні реєструється близько 350 тис. осіб, які потерпають від злочинів. Кожна сьома особа (50270, або 14,6\%), що реєструється як потерпілий у нашій країні, стає жертвою в Одеській (23 159, або 6,8\%), Миколаївській (13 631, або $3,95)$ чи Херсонській (13 480, або 3,9\%) областях. Більшість віктимізованих осіб в Україні й регіонах фіксується в містах і селищах міського тuny - 268928 (78\%). При цьому Причорноморський регіон характеризується нерівномірністю розподілу та підвищеним рівнем віктимізації населення саме на території обласних центрів.

Ключові слова: корислива злочинність проти власно$\mathrm{cmi}$, регіон, велике місто, Причорноморський регіон, жертва злочину, віктимна поведінка, запобігання злочинності.

В статье представлены результаты виктимологиче ской характеристики корыстных преступлений против собственности в большом городе Причерноморского региона Украины. Констатировано, что изучение виктими зации населения является одним из важных путей информирования населения с целью его защиты от корыстных преступлений против собственности.

Представлен обобщенный портрет жертвы корыстных преступлений против собственности в большом городе Причерноморья Украины. Выявлено, что ежегодно в нашей стране регистрируется около 350 тыс. лии, которые признаются потерпевшими от преступлений. Каждый седьмой потерпевший (50270, или 14,6\%) становится жертвой в Одесской (23159, или 6,8\%), Николаевской $(13631$, или 3,95\%) либо Херсонской области (13480, или 3,9\%). Большая часть виктимизированных лиц в Украине фиксируется в больших городах и городах сельского типа - 268928 (78\%). При этом Причерноморский регион характеризуется неравномерным распределением и повышенным уровнем виктимизации населения именно на территории областных центров.

Ключевые слова: корыстная преступность против собственности, регион, большой город, Причерноморский регион, жертва преступления, виктимное поведение, предупреждение преступности.

The article presents the results of the victimological characteristics of selfish crimes against property in the big city of the Black Sea region of Ukraine. It is stated that knowledge of the phenomenon of victimization of the population is one of the most important ways of informing the population in order to protect it from self-serving crimes against property.

Остроглядов О. І., 2019
A generalized portrait of a victim of self-serving crimes against property in the big city of the Black Sea coast of Ukraine is formulated. It is established that annually in our country there are about 350 thousand people who are victims of crimes. One in seven people $(50.270$, or $14.6 \%)$ registered as a victim in our country becomes a victim in Odessa (23 159, or 6.8\%), Mykolaiv (13 631, or 3.95), or in Kherson Oblast (13 480, or 3.9\%). The overwhelming majority of victimized persons in Ukraine and in the regions are recorded in cities and towns - 268928 (78\%). At the same time, the Black Sea region is characterized by uneven distribution and an increased level of victimization of the population on the territory of regional centers. Thus, if 3909 (29\%) of the registered victims in the region are annually victims in Kherson, then similar parameters in Mykolayiv make 5317 (39\%), and in Odesa 11347 (49\%) victims of crime. The vast majority of people who are victims of property crime are victims of theft: Odessa- $80 \%$, Mykolaiv - $80 \%$, Kherson - 88\%; victims of fraud were the second most prevalent: Odessa - 8.5\%, Mykolaiv - $14.5 \%$, Kherson 7.5\%; the risk of becoming victims of robberies and robberies in the city was also high: Odessa - 9.4\% and 1.8\%; Mykolaiv - $4.7 \%$ and $0.75 \%$; Kherson $-3.6 \%$ and $1 \%$ respectively.

The distribution of victims of self-serving crimes in the big city by age group is as follows: $7 \%$ of victims were under the age of 18 ; $14 \%$ - from 19 to 25 years; $25 \%$ - from 26 to 35 years; $30 \%$ from 36 to 45 years; $23 \%$ are older than 45 years.

Robberies and robberies in public are mostly committed in the evening and at night, and with the penetration of apartments (including theft) in most cases in the morning and day. Most apartment thefts in the big city commit in the morning (between 9 am and $1 \mathrm{pm}$ - about $70 \%$ of actions). It is at this time that many citizens are at work, in schools, and housewives are shopping. The rest of the thefts are committed in the evening, preferably from $10 \mathrm{pm}$ to $8 \mathrm{pm}$. The most criminogenic season for robberies in dormitories is winter and autumn (54\%), and for the central areas of the resort city - on the contrary, in the summer day and night (62\%). Victims of larceny, robbery, robbery and extortion committed in large cities are generally unfamiliar with the perpetrators and are not clearly victimized.

Key words: self-serving crime against property, region, big city, Black Sea region, victim of crime, victim behavior, crime prevention.

Постановка проблеми та іï актуальність. Сучасна криміногенна ситуація у великих містах України у сфері корисливих посягань на власність довгі роки характеризується як складна з негативними тенденціями, спрямованими на зростання. Для більшості корисливих злочинів проти власності, учинених у великих містах, саме віктимність особи часто водночас $\epsilon$ і зворотною стороною злочинності, і детермінуючим фактором, й обов'язковим елементом для поновлення порушених прав, й об'єктом захисту від протиправних дій. Отже, узагальнена інформація про віктимізацію часто $\epsilon$ важливим елементом для отримання правоохоронними органами комплексної картини не лише про законо- 
мірності місця, часу, способів і знарядь учинення злочину, а й про потенційних жертв, які стають об'єктами злочинних посягань. У сукупності це $\epsilon$ підґрунтям для налагодження ефективної профілактики, спрямованої на недопущення вчинення злочинів.

Наведене зумовлює необхідність актуалізації наукових досліджень, присвячених вивченню жертви корисливих злочинів проти власності у великих містах України.

Аналіз останніх досліджень і публікацій. Проблемам вивчення злочинності й жертви злочину у великих містах, у тому числі й у сфері охорони власності, у різні роки приділяли увагу як зарубіжні, так і вітчизняні вчені. Одним із фундаторів вітчизняної науки у сфері пізнання жертви злочину стали роботи В.О. Тулякова [23]. О.М. Джужа, В.В. Василевич і Є.М. Моісеєв вивчали віктимологічну характеристику й розробляли заходи запобігання загальнокримінальній корисливій злочинності [17, с. 124-144]. В.С. Батиргареєва досліджувала вказаний феномен у ході вивчення соціально-правових і кримінологічних проблем розбоїв, а пізніше рецидивної злочинності $[10 ; 11]$. О.Г. Кулик, І.В. Наумова, А.А. Бова вивчали соціально-демографічні та кримінологічні ознаки осіб, які потерпіли від корисливих злочинів проти власності [18, с. 282-290]. С.В. Албул розробив кримінологічну характеристика корисливо-насильницьких злочинів стосовно іноземних громадян і запропонував шляхи зниження рівня віктимності вказаної категорії громадян [2]. Є.Ф. Азаров працював над цією темою в межах запобігання корисливим злочинам на залізничному транспорті [1]; С.М. Алфьоров вивчав корисливу злочинність у розрізі аналізу та запобігання злочинності в курортному регіоні [4]. А.М. Бабенко приділяв увагу вивченню регіональних особливостей жертв корисливої злочинності проти власності [5; 6; 7; 8]. Із цього чітко простежується, що проблема вивчення жертви корисливої злочинності проти власності у великих містах Причорноморського регіону не була предметом самостійного аналізу.

Мета статті полягає в розробленні віктимологічної характеристики корисливої злочинності проти власності у великому місті Причорноморського регіону України.

Виклад основного матеріалу. Розкриваючи тему корисливої злочинності проти власності у великому місті, зазначимо, що крадіжки, шахрайства, грабежі, розбої й вимагання вже з давніх часів зараховують до примітивних форм вилучення чужого майна [20, с. 245]. С.В. Албул правильно наголошує, що основні способи їх здійснення не зазнали значних змін від самого моменту зародження людського суспільства. Уже в Законникові Хамурапі, що правив Вавилоном у XVIII ст. до н. е., містяться згадки про означені види посягань, які каралися стратою [2, с. 57; 23, с. 14]. Угорський історик Д. Варга вказує, що крадіжки, грабежі й розбої відмічалися вже в ранніх шумерійців [12, с. 29]. Поширеність корисливих злочинів проти власності в київській Русі деякі автори порівнюють із формуванням національної кримінальної традиції та професіоналізуванням злочинності загалом [2, с. 57]. Якщо сам феномен учинення корисливого злочину проти власності неодноразово вивчався у вітчизняній і зарубіжній літературі, то такий обов'язковий елемент учинення корисливих злочинів проти власності, як особа, що стає жертвою такої події, до сьогодні залишається недостатньо вивченим. Особливо це стосується осіб, які стають жертвами злочину в умовах великого міста. Разом із цим жертва злочину (потерпілий) $є$ важливим елементом у процесі вчинення злочину [17, с. 36]. За даними дослідження, у корисливих злочинах проти власності, учинених у південному мегаполісі, завжди $є$ жертва, яка потерпіла від злочину. За фактами вчинення корисливих злочинів проти власності у великому місті Причорномор'я України в слідчо-судовій практиці, як правило, виноситься постанова про визнання особи потерпілою [10, с. 146]. Відповідно до ст. 55 Кримінального процесуального кодексу (далі - КПК) України, потерпілою у кримінальному провадженні визнається фізична особа, якій кримінальним правопорушенням завдано моральної, фізичної або майнової шкоди, а також юридична особа, якій кримінальним правопорушенням завдано майнової шкоди [16]. Разом із зазначеним наголосимо, що в нашій країні, як і в усьому світі, дуже гостро стоїть питання відшкодування жертвам злочину завданої шкоди. Із цього приводу у 2005 році в Україні запроваджено Європейську конвенцію про відшкодування шкоди потерпілим від насильницьких злочинів, яку укладено 24 листопада 1983 року, уведено в дію 1 лютого 1988 року [21]. Виходячи зі змісту ст. 127 КПК України, відшкодування шкоди, завданої внаслідок учинення кримінального правопорушення, може здійснюватися в трьох випадках: з боку підозрюваного, обвинуваченого, а також за його згодою будь-якою іншою фізичною або юридичною особою на будь-якій стадії кримінального провадження; за результатами розгляду цивільного позову в межах кримінального провадження на підставі відповідного судового рішення; коштами з Державного бюджету у випадках, визначених законом.

Натепер, відповідно до чинної системи роботи правоохоронних органів в Україні, у випадках, коли злочинець у скоєнні злочину не встановлений, питання відшкодування завданої шкоди органами влади навіть не розглядається, це при тому що рівень розкриття цих злочинів становить від 30 до 45\% (таблиця 1), тобто більше ніж половина жертв корисливих злочинів проти власності не отримує жодної компенсації. Водночас більше ніж половина злочинців уникають відповідальності, що у свідомості населення створює ілюзію безкарності й вигідності ведення злочинного способу життя (таблиця 2).

Але навіть у більшості розкритих корисливих злочинах найчастіше самі злочинці не компенсують завданої шкоди, оскільки більшість із них або не мають роботи, або в них відсутні інші джерела постійного прибутку.

В Україні ще у 2006 році розроблено Законопроект «Про відшкодування за рахунок держави матеріальної шкоди громадянам, які потерпіли від злочину». У 2012 році депутати зареєстрували Проект Закону України «Про компенсацію шкоди жертвам насильницьких злочинів» [21]. Сьогодні жодного з тих Проектів так і не ухвалено й більшість жертв злочинів не отримує будьякої компенсації за потерпання від правопорушень. Уся відповідальність за наслідки злочину фактично покладається на саму жертву. У цьому сенсі пізнання феномена віктимізації населення розглядається одним із найважливіших шляхів інформування населення з метою недопущення його віктимізації від досліджуваної категорії злочинів.

Вивчаючи феномен віктимності, В.О. Туляков із цього приводу зазначає: під час правопорушення зловмисник 
посягає не на конкретну особу, а на знеособлену жертву; у свідомості злочинця жертва не має особистісних якостей; вона, як правило, одна з тих, «хто знаходиться на іншому боці» [22, с. 358]. Однак для групи корисливих злочинів проти власності жертва нерідко, крім абстрактного носія права власності, сприймається злочинцем як реальний носій особистих характеристик, урахування яких злочинцем $є$ необхідною умовою для обрання оптимальних і дійових заходів учинення злочину [2, с. 61]. Пізніше в процесі запобігання злочинності узагальнена інформація про жертв корисливих злочинів проти власності закладається в основу віктимологічної профілактики, зумовлює обрання тих або інших наборів заходів реагування за злочини.

У рамках дослідження варто погодитися із сучасними кримінологами, які звертають увагу на «кримінологічну однорідність феномена крадіжок, грабежів, розбоїв і вимагань», з огляду на спільність причинної детермінації. У цьому сенсі варто вести мову не лише про єдність детермінації вчинення злочинів у великому місті, а й про спільність детермінації віктимної поведінки [3, с. 141]. При цьому в контексті віктимної поведінки в мегаполісі варто розрізняти крадіжки, грабежі, розбої та вимагання, які вчиняються у приміщеннях, від аналогічних злочинів, що вчиняються в громадських містах. Основні відмінності полягають не лише в місці вчинення злочину, а й у характері вчинених злочинів. Жертви крадіжок, грабежів, розбоїв і вимагань, які вчиняються в громадських місцях, як правило, не знайомі зі злочинцями й не характеризуються яскраво вираженою віктимною поведінкою [14, с. 41], тоді як корисливі злочини, що вчиняються з проникненням у житло, часто характеризуються випадками прямого або опосередкованого знайомства жертви з одним із членів злочинного угрупування (посібник, організатор, підбурювач і т.д.). У реальному житті майбутні жертви нерідко допускають витоки інформації про способи свого життя, рід занять, матеріальне становище родини, планування майбутніх витрат, придбання кошторисів тощо.

Спільні риси між злочинами, що вчиняються в приміщеннях, і злочинами, що вчиняються в громадських місцях великих міст, спостерігаються лише серед корисливо-насильницьких кримінальних правопорушень (грабежі, розбої, вимагання) проти власності. Жертви таких злочинів найчастіше дезорієнтовані та налякані швидкістю й інтенсивністю нападу, нахабністю й агре-

Таблиця 1

Кількість облікованих кримінальних правопорушень та осіб, яким вручено повідомлення про підозру в учиненні злочинів проти власності, у Причорноморському регіоні України за 2018 рік

\begin{tabular}{|l|c|c|c|c|}
\hline \multicolumn{1}{|c|}{ Параметри } & Україна & Одеська & Миколаївська & Херсонська \\
\hline $\begin{array}{l}\text { Обліковано кримінальних правопорушень } \\
\text { у звітному періоді }\end{array}$ & 303850 & 20959 & 12194 & 10418 \\
\hline $\begin{array}{l}\text { Кримінальні правопорушення, у яких особам } \\
\text { вручено повідомлення про підозру }\end{array}$ & 106413 & 5528 & 4023 & 4791 \\
\hline Питома вага & $(35 \%)$ & $(26 \%)$ & $(33 \%)$ & $(45 \%)$ \\
\hline
\end{tabular}

Таблиця 2

Динаміка кримінальних правопорушень осіб, яким вручено повідомлення про підозру, та осіб, які потерпіли від злочинів, в Україні за 2014-2018 рр.

\begin{tabular}{|l|c|c|c|c|c|}
\hline & 2014 & $\mathbf{2 0 1 5}$ & $\mathbf{2 0 1 6}$ & $\mathbf{2 0 1 7}$ & $\mathbf{2 0 1 8}$ \\
\hline Кількість кримінальних правопорушень & 529139 & 565182 & 592604 & 523911 & 487133 \\
\hline Особи, яким вручено підозру & 199263 & 188099 & 159480 & 198477 & 191856 \\
\hline Особи, які потерпіли від злочинів & 393532 & 412689 & 444617 & 374238 & 344780 \\
\hline
\end{tabular}

Таблиця 3

Кількість осіб, які потерпіли від кримінальних правопорушень, у населених пунктах Причорноморського регіону

\begin{tabular}{|l|c|c|c|c|}
\hline \multicolumn{1}{|c|}{ Параметри } & Україна & Одеська обл. & Миколаївська обл. & Херсонська обл. \\
\hline Загальна кількість & 344780 & 23159 & 13631 & 13480 \\
\hline у містах і селищах міського типу & $268928(78 \%)$ & $17601(76 \%)$ & $10087(74 \%)$ & $9166(68 \%)$ \\
\hline в обласному центрі & $103434(30 \%)$ & $11347(49 \%)$ & $5317(39 \%)$ & $3909(29 \%)$ \\
\hline у сільській місцевості & $75852(22 \%)$ & $5558(24 \%)$ & $3544(26 \%)$ & $4314(32 \%)$ \\
\hline
\end{tabular}

Кількість осіб, які потерпіли від кримінальних правопорушень, у населених пунктах

Таблиця 4 Причорноморського регіону

\begin{tabular}{|l|c|c|c|c|}
\hline \multicolumn{1}{|c|}{ Параметри } & Україна & Одеська обл. & Миколаївська обл. & Херсонська обл. \\
\hline $\begin{array}{l}\text { Загальна кількість потерпі- } \\
\text { лих від корисливих злочинів } \\
\text { проти власності }\end{array}$ & 260998 & 18147 & 10147 & 9900 \\
\hline Крадіжки & $217859(83 \%)$ & $14563(80 \%)$ & $8122(80 \%)$ & $8692(88 \%)$ \\
\hline Шахрайства & $27413(10 \%)$ & $1552(8,5 \%)$ & $1474(14,5 \%)$ & $747(7,5 \%)$ \\
\hline Грабежі & $13295(5 \%)$ & $1707(9,4 \%)$ & $474(4,7 \%)$ & $357(3,6 \%)$ \\
\hline Розбої & $2431(0,93 \%)$ & $325(1,8 \%)$ & $77(0,75 \%)$ & $104(1 \%)$ \\
\hline
\end{tabular}


сивністю дій зловмисника. Вони не в змозі вжити адекватні нападу заходи протидії. Як правило, жертви через фізичну та психологічну перевагу злочинця демонструють пасивну поведінку, а відсутність опору додає злочинцям упевненості в можливості безкарного вчинення злочину [14, с. 41$]$.

У кримінологічній літературі неодноразово доводилося, що віктимізація $\epsilon$ зворотною стороною процесу криміналізації. Відповідно, i характеристика віктимізації, як правило, наводиться виходячи з аналізу іï кількісно-якісних параметрів, детермінації та особи потерпілого [13, с. 24-25]. Інші автори вказують, що віктимізація серед населення характеризується кількісними та якісними показниками, які відображають сукупності членів суспільства або сімей, які постраждали від злочинів [17, с. 71]. У рамках дослідження віктимологічна характеристика міської корисливої злочинності проти власності передбачає аналіз стану віктимізації; її структурні параметри (у тому числі типи й види віктимності); динаміку віктимізації; географію, екологію й топографію віктимізації [17, с. 71].

Аналіз статистичних даних Генеральної прокуратури України вказує, що віктимогенна ситуація в Україні продовжує залишатися доволі складною (таблиця 2).

Щорічно в нашій країні реєструється близько 350 тис. осіб, які потерпають від злочинів (таблиця 2). Кожна сьома особа (50270, або 14,6\%), що реєструється як потерпілий у нашій країні, стає жертвою в Одеській (23 159, або 6,8\%), Миколаївській (13 631, або 3,95) чи Херсонській (13 480, або 3,9\%) областях. Більшість віктимізованих осіб в Україні та регіонах фіксується в містах і селищах міського типу - 268928 (78\%). При цьому Причорноморський регіон характеризується нерівномірністю розподілу та підвищеним рівнем віктимізації населення саме на території обласних центрів. Так, якщо в м. Херсоні щорічно стають жертвами 3909 (29\%) осіб від зареєстрованих потерплих у регіоні, то аналогічні параметри в м. Миколаєві становлять 5317 (39\%), а в м. Одесі - 11347 (49\%) жертв злочинів (таблиця 3).

У великих містах Причорноморського регіону найчастіше стають жертвами від корисливих злочинів проти власності. Більшість осіб потерпає від крадіжок: Одеса - 80\%, Миколаїв - 80\%, Херсон - 88\%; другими за поширеністю виявилися жертви від шахрайств: Одеса 8,5\%, Миколаїв - 14,5\%, Херсон - 7,5\%; високим також виявився ризик стати потерпілим від грабежів і розбоїв: Одеса - 9,4\% та 1,8\%; Миколаїв - 4,7\% та 0,75\%; Херсон $3,6 \%$ та $1 \%$ відповідно (таблиця 4).

Не менш важливими $є$ вікові параметри віктимності від корисливих злочинів проти власності. За даними кримінологічних досліджень, розподіл потерпілих від корисливих злочинів у великому місті за віковими групами є таким: 7\% потерпілих мали вік до 18 років; $14 \%$ від 19 до 25 років; 25\% - від 26 до 35 років; 30\% - від 36 до 45 років; $23 \%$ - старші за 45 років [17, с. 130]. Цікавим виявився той факт, що вікові межі осіб, які вчиняють, і таких, що потерпають від корисливих злочинів, у великому місті майже ідентичні. Поряд із цим пік віктимного віку потерпілих від кишенькових крадіжок від 36 до 45 років - 31,3\%; 46 і старші - 29,5\%; від квартирних крадіжок 36-45 років - 32,7\%; від шахрайства 26-35 років - 28,3\%; 36-45 років - 26,4\% [17, с. 130$]$.

Як свідчать результати кримінологічних досліджень, крадіжки, грабежі, розбої, вимагання та шах- райства $є$ найбільш типовими злочинами великих міст України, які вчиняються практично в будь-яку пору року. Разом із цим інтенсивність ї учинення прямо залежить від часових, сезонних і територіальних факторів. Наприклад, грабежі та розбої в громадських місцях учиняються переважно у вечірній і нічний час, а з проникненням у квартири (у тому числі й крадіжки) у більшості випадків - зранку й удень. Більшість квартирних крадіжок у великому місті учиняють у ранковий час (у період із 9 до 13 год. - близько 70\% діянь). Саме в цей час багато громадян перебуває на роботі, у навчальних закладах, домогосподарки здійснюють покупки. Решту крадіжок учиняють у вечірній час, переважно з 22-ї до 24-ї год. Найбільш криміногенним сезоном для грабежів у спальних районах $€$ зима й осінь (54\%), а для центральних районів курортного міста, навпаки, - літо (удень і вночі) (62\%) [17, с. 125$128 ; 15$, с. $159-162 ; 17$, с. 7-9]. Проведеним дослідженням не зафіксовано істотних сезонних відмінностей для розбоїв і вимагань. Разом із цим виявлено особливості, які пов'язані з характером архітектурної забудови та інфраструктури: найчастіше грабежі, розбійні напади та вимагання вчиняються на територіях із нерозвиненою структурою - тихі вулиці, недалеко від зупинок і транспорту в погано освітлених «спальних районах», а також у центральних із наявністю великої кількості шляхів відходу [17, с. 125-128; 15, с. 159-162; 9, с. 7-9]. «Вуличні» шахрайства у великому місті Причорномор'я $€$ найбільш характерними влітку - протягом курортного сезону, тоді як для вчинення шахрайств з нерухомістю, у комерційній сфері та кібершахрайств не спостерігається помітно вираженої сезонної та часової залежності [19, с. 92-115]. Представлена інформація може виявитися корисною для інформаційноаналітичного забезпечення роботи правоохоронних органів з метою віктимологічної профілактики корисливих злочинів проти власності в умовах великого міста Причорноморського регіону материкової України.

Висновки. Проведеним кримінологічним дослідженням вдалося сформувати узагальнений портрет жертви корисливих злочинів проти власності у великому місті Причорномор'я України. Щорічно в нашій країні реєструється близько 350 тис. осіб, які потерпають від злочинів. Кожна сьома особа (50270, або 14,6\%), що реєструється як потерпілий у нашій країні, стає жертвою в Одеській (23 159, або 6,8\%), Миколаївській (13 631, або 3,95$)$ чи Херсонській $(13480$, або 3,9\%) областях. Більшість віктимізованих осіб в Україні та регіонах фіксується в містах і селищах міського типу - 268928 (78\%). При цьому Причорноморський регіон характеризується нерівномірністю розподілу та підвищеним рівнем віктимізації населення саме на території обласних центрів. Так, якщо в м. Херсоні щорічно стають жертвами 3909 (29\%) осіб від зареєстрованих потерплих у регіоні, то аналогічні параметри в м. Миколаєві становлять 5317 (39\%), а в м. Одесі - 11347 (49\%) жертв злочинів. Більшість осіб, які стають жертвами злочинів проти власності, потерпає від крадіжок: Одеса - 80\%, Миколаїв - 80\%, Херсон - 88\%; другими за поширеністю виявилися жертви від шахрайств: Одеса - 8,5\%, Миколаїв - 14,5\%, Херсон - 7,5\%; високим також виявився ризик стати потерпілим у місті від грабежів і розбоїв: Одеса - 9,4\% та 1,8\%; Миколаїв - 4,7\% та 0,75\%; Херсон $3,6 \%$ та $1 \%$ відповідно. 
Розподіл потерпілих від корисливих злочинів у великому місті за віковими групами є таким: 7\% потерпілих мали вік до 18 років; 14\% - від 19 до 25 років; 25\% від 26 до 35 років; 30\% - від 36 до 45 років; 23\% - старші за 45 років.

Грабежі та розбої в громадських місцях учиняються переважно у вечірній і нічний час, а з проникненням у квартири (у тому числі й крадіжки) у більшості випадків - зранку й удень. Більшість квартирних крадіжок у великому місті вчиняють у ранковий час (у період з 9 до 13 год. - близько 70\% діянь). Саме в цей час багато громадян перебуває на роботі, у навчальних закладах, домогосподарки здійснюють покупки. Решту крадіжок учиняють у вечірній час, переважно з 22-ї до 24-ї год. Найбільш криміногенним сезоном для грабежів у спальних районах $є$ зима й осінь (54\%), а для центральних районів курортного міста, навпаки, - літо (удень і вночі) (62\%). Жертви крадіжок, грабежів, розбоїв і вимагань, які вчиняються у великих містах, як правило, не знайомі зі злочинцями й не характеризуються яскраво вираженою віктимною поведінкою.

\section{Література}

1. Азаров Є.Ф. Запобігання корисливим злочинам на пасажирському залізничному транспорті України : автореф. дис. ... канд. юрид. наук : 12.00.08. Харків, 2017. 20 с.

2. Албул С.В. Кримінологічна характеристика корисливо-насильницьких злочинів відносно іноземних громадян : дис. ... канд. юрид. наук : 12.00.08. Одеса, 2005. 194 с.

3. Алиев Н.Т. Современный грабеж: криминологические проблемы. Бизнес в законе. Экономико-юридический журнал. 2011. № 6. С. 140-143.

4. Алфьоров С.М. Діяльність органів внутрішніх справ по протидії злочинності у курортних регіонах (кримінологічне дослідження на матеріалах Запорізької області) : дис. ... канд. юрид. наук : 12.00.08. Харків, 2003. 197 с.

5. Бабенко А.М. Запобігання злочинності в регіонах України: концептуально-методологічний та праксеологічний вимір : монографія. Одеса : ОДУВС, 2014. 416 с.

6. Бабенко А.М. Регіональні особливості злочинності у містах та сільських районах Запорізької, Дніпропетровської та Харківської областей. Питання боротьби зі злочинністю : збірник наукових праць / редкол. : В.І. Борисов та ін. Харків : Право, 2018. С. 42-60.

7. Бабенко А.М. Територіально-просторовий аналіз злочинності у населених пунктах Одеської області. Вісник Асоціації кримінального права України. 2017. № 2 (9). URL: http: / / nauka.nlu.edu.ua/wp-content/uploads/2017/12/11_ Babenko.pdf (дата звернення: 10.02.2019).

8. Бабенко А.М., Конопельський В.Я., Чекмарьова І.М. Кримінологічна характеристика та запобігання злочинності у прикордонних регіонах Причорномор'я материкової України : монографія. Харків : Право, 2019. 264 с.

9. Басков А.В. Виктимологическая профилактика корыстно-насильственных преступлений, совершаемых в общественных местах : дисс. ... канд. юрид. наук : 12.00.08. Москва, 2010. 180 с.

10. Батиргареєва В.С. Кримінологічна характеристика та попередження розбоїв, поєднаних з проникненням у житло : монографія. Харків : Одіссей, 2003. 256 с.

11. Батиргареєва В.С. Рецидивна злочинність в Україні: соціально-правові та кримінологічні проблеми : монографія. Харків : Право, 2009. 576 с.

12. Варга Д. Древний Восток. У начал истории письменности. Будапешт : Изд-во Корвина, 1979. 204 с.

13. Виктимологическая характеристика региональной преступности и ее предупреждение : монография / С.А. Корягина, Ж.В. Островских, А.Л. Репецкая, Д.В. Синьков и др. ; под ред. : А.Л. Репецкой. Москва : Academia, 2009. 304 c.

14. Каменских О.В. Виктимологическая профилактика корыстно-насильственных преступлений (грабежей и разбойных нападений), совершаемых в общественных местах и на улицах, на примере УРФО. Виктимология. 2019. № 1 (19). C. 40-45.

15. Копилова М. Віктимологічний аспект профілактики злочинів проти власності на курортах АР Крим. Підприємництво. Господарство. Право. 2010. № 9. С. 159-162.

16. Кримінальний процесуальний кодекс України : Закон України від 13 квітня 2012 р. № 4651-VI (зі змінами станом на 19.09.2019). Відомості Верховної Ради України. 2013. № 9-10, 11-12, 13. Ст. 88.

17. Кримінологічна віктимологія : навчальний посібник / Є.М. Моісеєв, О.М. Джужа, В.В. Василевич та ін. ; за заг. ред. О.М. Джужі. Київ : Атіка, 2006. 352 с.

18. Кулик О.Г., Наумова І.В., Бова А.А. Злочинність в Україніб фактори, тенденції, протидія: (2002-2014 рр.) : монографія. Київ : ДНДІ МВС України, 2015. 364 с.

19. Лефтеров Л.В. Запобігання підрозділами Національної поліції шахрайству, що вчиняється з використанням засобів електронних комунікацій : дис. ... канд. юрид. наук : 12.00.08. Одеса : Одеський державний університет внутрішніх справ, 2019. 284 с.

20. Лунеев В.В. Преступность XX века. Мировой криминологический анализ. Москва: Норма, 1999. 516 с.

21. Мрії про соціальну державу, або Про державні компенсації жертвам насильства. URL: http://www.pravo.org.ua/ua/news/5907 (дата звернення: 10.02.2019).

22. Туляков В.А. Учение о жертве преступления: социально-правовые основы : дисс. ... докт. юрид. наук : 12.00.08. Одесса, 2002. 394 с.

23. Хрестоматия по истории государства и права зарубежных стран / под ред. З.М. Черниловского. Москва : Юрид. лит., 1984. 472 с.

Остроглядов О. І., майор полічії, начальник Приморського районного відділу поліції у м. Одеса Головного управління Національної поліції в Одеській області 